\title{
Growth, Productivity, Nutrient uptake and Economics of Hybrid maize (Zea mays L.) as Influenced by Precision Nutrient Management
}

\author{
Gopal Sing Bhuiya ${ }^{1}$, Tanmoy Shankar ${ }^{2 *}$, Mahua Banerjee ${ }^{1}$ and G.C. Malik ${ }^{1}$
}

${ }^{1}$ Palli Siksha Bhavana, Visva-Bharati, Sriniketan, Birbhum, West Bengal, India

${ }^{2}$ Department of Agronomy, M.S. Swaminathan School of Agriculture, Centurion University Technology and Management, Paralakhemundi, Odisha

*Corresponding author: tanmoy.shankar125@gmail.com (ORCID ID: 0000-0003-1888-9912)

Paper No. 839

Received: $12-01-2020$

Revised: $17-04-2020$

Accepted: 29-05-2020

\begin{abstract}
The field experiment was carried out at the farmer's field in Chella Kamarpara village, Chella G.P, Chella Mouza of Illambazar Block, Birbhum, West Bengal which is situated at $23^{\circ} 37.374^{\prime}$ latitude and $87^{\circ} 37.170^{\prime} \mathrm{E}$ longitudes with an average altitude of $58.9 \mathrm{~m}$ above mean sea level under sub-humid, sub-tropical belt under the prevailing climatic conditions of West Bengal during the Kharif season of 2013. The experiment consisted of the five levels of nutrient management i.e., $\mathrm{N}_{1}$ : State recommendation (150:75:75), $\mathrm{N}_{2}$ : Nutrient expert (NE) recommendation (120:34:51), $\mathrm{N}_{3}$ : Farmers practices (80:40:40), and $\mathrm{N}_{4}$ : Basal application of 50:75:75 with split $\mathrm{N}$ application on basis of LCC (leaf colour chart), $\mathrm{N}_{5}$ :control and two level of varieties viz. $\mathrm{V}_{1}$ : Sona and $\mathrm{V}_{2}$ : Rajkumar, the total number of treatment combinations are ten, which were replicated thrice and was laid out in factorial randomized block design (FRBD). To evaluate the effect of nutrient management on the growth, productivity and economics of hybrid maize cultivation. Nutrient management has played an important role in achieving sustainability of grain production. The chemical fertilizer consumption coupled with their limited production, fertilizer cost, soil health and pollution have given rise to interest in precision nutrient management tools. It was the found that the Growth, productivity, nutrient uptake and economics of hybrid maize (Zea mays L.) as influenced by precision nutrient management which was significantly affected by different level of nutrient management and varieties. Whereas, LCC based application of fertilizer gave better result than all other treatment but it was also statistically at par with Nutrient expert based recommendation.

\section{Highlights}

(0 User-friendly nutrient decision support tool that enables researchers, extension experts and industry.

( Based on nutrient expert tool is a better option of nutrient management for maize crops.

0 Enhance productivity and sustainability of maize cultivation.
\end{abstract}

Keywords: Hybrid Maize, Leaf colour chart (LCC), Nutrient Expert (NE), Growth Yield, Economics

Maize is grown for cereal grain as well as fodder in tropical, sub-tropical and temperate regions of the world. Maize has multiple uses in other than food industries and ranked third among the world cereal crop production (Kumar \& Jhariya 2013). Eastern India is one of the most populous and intensively cultivated regions in the world. Smallholder farmers of the region. However, have low resource availability and profitability from predominantly cereal-based cropping system Meena et al. (2014). At present, maize-growing area is increasing rapidly in Eastern India over the last decades, especially a in states like West Bengal and Odisha. Nutrient management has played a crucial role in achieving sustainability in food grain production. The precise use of nutrient management of $\mathrm{N}$ fertilizer in Maize 
is compelling for both economic and environmental reasons. Static fertilizer recommendations based on average response lead to excessive fertilization in some years and inadequate fertilizers in years with high $\mathrm{N}$ loss. The uncertainty in optimum $\mathrm{N}$ rate makes the risks for profit loses which is exacerbating by the asymmetric profit response of maize to $\mathrm{N}$ rates. The associated higher cost of under fertilization relative to over fertilization drives farmers to apply imbalanced rates. This uncertainty can be addressed by providing more accurate location and time specific. However, in the fertilizer recommendations for maize available to farmers are "blanket" in nature and do not take into account the spatial variability in indigenous nutrient supplying capacity of different farms and the variable resource endowment of farmers. Such recommendations often fail to supply required amount of nutrients to crops, leading to loss of productivity and farm profit. The Nutrient Expert for Maize, a nutrient decision support tool based on site-specific nutrient management (SSNM) principles, has been developed to provide appropriate nutrient management strategy for individual farm field based on biophysical (spatial and temporal variability of nutrient availability in farmers' field) and socio-economic (resource available to the farmer) characteristics of the farm. This decision making system, developed in 201011 , is an easy-to-use, interactive computer-based decision tool which provide rapidly nutrient recommendation for individual farmers' field in presence or absence of soil testing data. (Pampolino et al. 2012; Satyanarayana et al. 2013).

\section{MATERIALS AND METHODS}

A field experiment was conducted to study the red and lateritic belt of West Bengal, during kharif season of 2013 at Farmer's field of village Chella, District Birbhum under red and lateritic belt of West Bengal. The field was the sub-humid, semi arid region of West Bengal. Analysis of Experimental soil The soil of the experimental plot was sandy loam in texture, acidic in soil reaction with low level of organic carbon and available nitrogen but medium level of available phosphorus and potassium. The composite soil samples from $0-15 \mathrm{~cm}$ soil layer were collected before commencement of the experiment and analyzed to determine the physio-chemical properties of the experimental plot. The experiment was laid out in factorial randomized block design (FRBD). The total combinations of treatment are ten and replicated thrice. The experiment was carried out with five levels of fertilizer i.e., $\mathrm{F} 1$ (control), $\mathrm{F}_{2}$ (state recommendation 150:75:75 kg N: $\mathrm{P}_{2} \mathrm{O}_{5}: \mathrm{K}_{2} \mathrm{O}$ ha${ }^{1}$ ), $\mathrm{F}_{3}$ (farmers practices 80:40:40 kg N:P $\mathrm{O}_{5}: \mathrm{K}_{2} \mathrm{O} \mathrm{ha}^{-1}$ ), $\mathrm{F}_{4}$ (Nutrient expert巴 120:34:51 kg N: $\mathrm{P}_{2} \mathrm{O}_{5}: \mathrm{K}_{2} \mathrm{O}$ ha-1) and $\mathrm{F}_{5}$ (Basal application of 50:75:75 kg N:P $\mathrm{O}_{5}: \mathrm{K}_{2} \mathrm{O}$ ha $^{-1}$ with split $\mathrm{N}$ application on basis of LCC) and two varietal level viz., $V_{1}$ (Rajkumar) \& $V_{2}$ (Sona). The three splits of nitrogen were applied at the rate of $25 \mathrm{~kg} \mathrm{~N} / \mathrm{ha}$ in each split thus the total dose of nitrogen applied was at the rate of $125 \mathrm{~kg} \mathrm{~N} /$ ha. The standard package of practices applied for successful crop stand.

\section{RESULTS AND DISCUSSION}

\section{Plant height}

The plant heights of two maize hybrids were influenced by different levels of fertilizers application at harvest of crop were statistically analyzed and presented in the Table 1 . The maize hybrid Rajkumar proved superior in respect of plant height, dry matter and leaf are index. The plant height of Rajkumar was significantly higher than that of Sona at harvest stage . Similar result was observed by Bunker et al. (2011). Nutrient Expert and LCC based application of fertilizer produced significantly higher plant height compared to the state recommendation, farmer practices and control treatment. Nutrient Expert ${ }^{\circledR}$ based application of fertilizer produced significant positive interaction effect between the variety Rajkumar and Sona. Similar result was observed with the dry matter produced per plant with different levels of nutrient management treatments which produce significantly influenced in total dry matter at 90 DAS. All the levels of nutrient management were found to significantly higher than control (no fertilizer application). Results are in conformity with the findings of Paramasivan et al. (2011). The Leaf Area Index of the maize increased steadily up to the 60 DAS and then declined due to senescence of older leaves as the crop progressed towards its maturity. The Leaf area index was significantly increased by the treatment with LCC and Nutrient Expert based application of fertilizer gave the highest leaf area 
index which was observed at 60 DAS compared to all other treatments and in contest of variety Rajkumar produced higher LAI than Sona. Similar result was observed that the evident that nutrient dose provided by NE and LCC practice fulfills the nutrient requirement of the crop when required hence better growth attributes (Hou et al. 2013 and Singh et al. 2017).

Table 1: Effect of nutrient management and varieties on growth attribute of Maize

\begin{tabular}{|c|c|c|c|}
\hline \multirow[b]{2}{*}{ Treatments } & \multicolumn{3}{|c|}{ Growth attributes } \\
\hline & $\begin{array}{l}\text { Plant } \\
\text { height } \\
(\mathrm{cm}) \\
90 \text { DAS }\end{array}$ & $\begin{array}{l}\text { Dry matter } \\
\text { accumulation } \\
\text { (g/plant) } 90 \\
\text { DAS }\end{array}$ & $\begin{array}{l}\text { Leaf area } \\
\text { index } \\
\text { (LAI) } 60 \\
\text { DAS }\end{array}$ \\
\hline \multicolumn{4}{|c|}{ Fertilizer } \\
\hline $\begin{array}{l}F_{1}: \text { State } \\
\text { Recommendation }\end{array}$ & 181.3 & 97.8 & 3.5 \\
\hline $\mathrm{F}_{2}:$ Nutrient Expert ${ }^{\circledast}$ & 182.2 & 98.5 & 3.8 \\
\hline $\mathrm{F}_{3}:$ Farmer's practice & 177.6 & 97.2 & 3.0 \\
\hline $\begin{array}{l}\mathrm{F}_{4}: \text { LCC based } \\
\text { application }\end{array}$ & 182.9 & 99.1 & 3.9 \\
\hline $\mathrm{F}_{5}:$ Control & 169.4 & 94.4 & 2.9 \\
\hline SEm \pm & 1.5 & 0.4 & 0.2 \\
\hline $\mathrm{CD}(\mathrm{P}=0.05)$ & 4.5 & 1.3 & 0.5 \\
\hline \multicolumn{4}{|c|}{ Variety } \\
\hline $\mathrm{V}_{1}$ : Sona & 175.1 & 95.9 & 3.2 \\
\hline $\mathrm{V}_{2}$ : Rajkumar & 182.3 & 98.8 & 3.7 \\
\hline SEm \pm & 2.3 & 0.7 & 0.2 \\
\hline $\mathrm{CD}(\mathrm{P}=0.05)$ & 7.1 & 2.0 & $0.7(\mathrm{NS})$ \\
\hline
\end{tabular}

\section{Yield}

Grain yield recorded at $15 \%$ moisture as influenced by varieties and different levels of nutrient management have been presented in Table 2. The grain yield of Rajkumar (38.8 q/ha) variety was significantly higher grain yield than that of Sona variety ( $31.3 \mathrm{q} / \mathrm{ha})$. This may be due to the superiority of Rajkumar variety over Sona variety with respect to vegetative growth and yield components. Results are in conformity with findings of Bunker et al. (2011).The grain yield was highest when fertilizer application was done based on Nutrient Expert recommendation and it was statistically at par with LCC based application and State recommendation. The percentage increase in grain yield from Nutrient Expert ${ }^{\circledR}$ based recommendation over control, farmers practices, state recommendation and LCC based application of fertilizer were $126.4 \%, 30.7 \%, 3.1 \%$ and $1.5 \%$ respectively. Similar result was observed by Nottidge, et al. (2011) Like as grain yield, Rajkumar variety produced higher Stover yield of $55.0 \mathrm{q} /$ ha over that of Sona variety ( $47.7 \mathrm{q} / \mathrm{ha}$ ) but both the values were statistically at par. However, in case of fertilizer application also observed similar result as in grain yield. The Stover yield was highest (65.9 q/ha) in NE and it was statistically at par with LCC based application and State recommendation. Similar results were reported by Wang et al. (2014). The harvest index doesn't very much in the variety level. The Rajkumar variety recorded maximum harvest index of 41.1 which was statistically at par with f Sona variety (38.9). The fertilizer application through NE recorded highest harvest index (41.3) which was followed by LCC but significantly greater than control. Nutrient expert gave a dynamic adjustment of fertilizer application rates based on crop requirement. Due to the judicious nutrient management under NE based nutrient management practice has led to the higher grain, stover and biological yield over farmer's practice of nutrient management and control. Similar result was observed by Tetarwal et al. (2011); Xinpeng et al. (2014) and Khanal et al. (2017).

Table 2: Grain yield, Stover yield and harvest index of maize hybrids as affected by nutrient management

\begin{tabular}{|c|c|c|c|}
\hline \multirow[b]{2}{*}{ Treatments } & \multicolumn{3}{|c|}{ Yield } \\
\hline & $\begin{array}{l}\text { Grain yield } \\
\text { (q/ha) }\end{array}$ & $\begin{array}{l}\text { Stover } \\
\text { yield (q/ha) }\end{array}$ & $\begin{array}{l}\text { Harvest } \\
\text { index }(\%)\end{array}$ \\
\hline \multicolumn{4}{|c|}{ Fertilizer } \\
\hline $\begin{array}{l}\mathrm{F}_{1}: \text { State } \\
\text { Recommendation }\end{array}$ & 35.2 & 56.9 & 38.2 \\
\hline $\begin{array}{l}\mathrm{F}_{2}: \text { Nutrient } \\
\text { Expert }^{\circledR}\end{array}$ & 46.4 & 65.9 & 41.3 \\
\hline $\begin{array}{l}\mathrm{F}_{3}: \text { Farmer's } \\
\text { practice }\end{array}$ & 26.7 & 46.3 & 36.6 \\
\hline $\begin{array}{l}\mathrm{F}_{4}: \text { LCC based } \\
\text { application }\end{array}$ & 44.7 & 64.9 & 40.8 \\
\hline $\mathrm{F}_{5}:$ Control & 11.4 & 42.9 & 21.0 \\
\hline SEm \pm & 0.6 & 2.0 & 1.2 \\
\hline $\mathrm{CD}(\mathrm{P}=0.05)$ & 1.7 & 5.8 & 3.5 \\
\hline \multicolumn{4}{|c|}{ Variety } \\
\hline $\mathrm{V}_{1}$ : Sona & 31.3 & 47.7 & 38.9 \\
\hline $\mathrm{V}_{2}:$ Rajkumar & 38.8 & 55.0 & 41.1 \\
\hline SEm \pm & 0.9 & 3.1 & 1.8 \\
\hline $\mathrm{CD}(\mathrm{P}=0.05)$ & 2.7 & 9.14(NS) & $5.46(\mathrm{NS})$ \\
\hline
\end{tabular}

\section{Nutrient Uptake}

The data pertaining to $\mathrm{N}$ uptake in maize grain and stover was presented in Table 3. Among the 
Table 3: Nutrient uptake in Maize cultivation as affected by nutrient management practices and varieties

\begin{tabular}{|c|c|c|c|c|c|c|c|c|c|}
\hline \multicolumn{10}{|c|}{ Nutrient uptake (kg/ha) } \\
\hline \multirow[t]{2}{*}{ Treatments } & \multicolumn{3}{|c|}{ Nitrogen } & \multicolumn{3}{|c|}{ Phosphorous } & \multicolumn{3}{|c|}{ Potassium } \\
\hline & Grain & Stover & Total & Grain & Stover & Total & Grain & Stover & Total \\
\hline \multicolumn{10}{|c|}{ Fertilizer } \\
\hline$\overline{\mathrm{F}_{1}}$ & 54.1 & 30.1 & 84.2 & 15.6 & 10.2 & 25.8 & 11.0 & 79.4 & 90.4 \\
\hline $\mathrm{F}_{2}$ & 55.4 & 30.2 & 85.6 & 16.3 & 10.2 & 26.6 & 11.7 & 83.1 & 94.8 \\
\hline $\mathrm{F}_{3}$ & 37.6 & 21.4 & 59.0 & 12.1 & 7.7 & 19.8 & 8.1 & 63.3 & 71.4 \\
\hline $\mathrm{F}_{4}$ & 54.9 & 31.4 & 86.3 & 16.6 & 10.9 & 27.5 & 11.4 & 84.7 & 96.1 \\
\hline $\mathrm{F}_{5}$ & 21.2 & 19.6 & 40.8 & 6.8 & 7.4 & 14.2 & 4.5 & 57.8 & 62.3 \\
\hline SEm \pm & 1.0 & 1.1 & 1.7 & 0.3 & 0.5 & 0.5 & 0.4 & 2.6 & 2.6 \\
\hline $\mathrm{CD}(\mathrm{P}=0.05)$ & 2.8 & 3.4 & 5.1 & 0.7 & 1.5 & 1.6 & 1.1 & 7.8 & 7.7 \\
\hline \multicolumn{10}{|c|}{ Variety } \\
\hline $\mathrm{V}_{1}$ & 36.9 & 23.1 & 60.0 & 11.7 & 8.1 & 19.8 & 8.0 & 67.3 & 75.3 \\
\hline $\mathrm{V}_{2}$ & 52.3 & 30.0 & 82.3 & 15.3 & 10.5 & 25.7 & 10.7 & 80.0 & 90.7 \\
\hline SEm \pm & 1.5 & 1.8 & 2.7 & 0.4 & 0.8 & 0.9 & 0.6 & 4.2 & 4.1 \\
\hline $\mathrm{CD}(\mathrm{P}=0.05)$ & 4.5 & 5.4 & 8.1 & 1.2 & $2.40(\mathrm{NS})$ & 2.5 & 1.7 & 12.3 & 12.2 \\
\hline
\end{tabular}

two varieties, higher $\mathrm{N}$ uptake in grain, Stover and total $\mathrm{N}$ uptake was observed in Rajkumar variety. Among all the nutrient management treatments, the data revealed that the highest $\mathrm{N}$ uptake by maize grain $(55.4 \mathrm{~kg} / \mathrm{ha})$ was recorded in Nutrient Expert which was significantly higher than all other treatments. The highest $\mathrm{N}$ uptake by maize Stover $(31.3 \mathrm{~kg} / \mathrm{ha})$ was recorded in LCC based application of fertilizer and it was at par with Nutrient expert based recommendation. The highest total $\mathrm{N}$ uptake by maize $(86.3 \mathrm{~kg} / \mathrm{ha})$ was also observed when there was LCC based application of fertilizer but it was also at par with Nutrient expert based recommendation. The lowest $\mathrm{N}$ uptake $(\mathrm{kg} / \mathrm{ha})$ of maize grain $(21.2 \mathrm{~kg} / \mathrm{ha})$, Stover $(19.6 \mathrm{~kg} / \mathrm{ha})$ and total $\mathrm{N}$ uptake was recorded in control (no fertilizer). The data revealed that the P uptake by maize grain (16.6 kg/ha), Stover $(11.0 \mathrm{~kg} / \mathrm{ha})$ and Total P uptake $(27.51 \mathrm{~kg} / \mathrm{ha})$ was highest in LCC based application of fertilizer which was significantly higher than all other treatments but statistically at par with Nutrient expert based recommendation. Similar result observed in P uptake of grain, stover and total uptake where as the lowest $P$ uptake of Maize grain $(6.8 \mathrm{~kg} / \mathrm{ha})$, Stover $(7.4 \mathrm{~kg} / \mathrm{ha})$, and Total $\mathrm{P}$ uptake $(14.2 \mathrm{~kg} / \mathrm{ha})$ were observed where there was no application of fertilizers. The $\mathrm{K}$ uptake by maize grain $(11.7 \mathrm{~kg} / \mathrm{ha})$ was highest in Nutrient expert based application of fertilizer. Highest $\mathrm{K}$ uptake by maize stover $(84.7 \mathrm{~kg} / \mathrm{ha})$ and total $\mathrm{K}$ uptake $(96.1$ $\mathrm{kg} / \mathrm{ha}$ ) was observed in LCC based application of fertilizer which was statistically at par with Nutrient Expert recommendation and State recommendation.
The lowest $\mathrm{K}$ uptake (kg/ha) of Maize grain (4.48 $\mathrm{kg} / \mathrm{ha})$, Stover $(57.8 \mathrm{~kg} / \mathrm{ha})$ and total $\mathrm{K}$ uptake $(62.3$ $\mathrm{kg} / \mathrm{ha}$ ) were observed when there was no fertilizer application. In Rajkumar variety $\mathrm{K}$ uptake $(\mathrm{kg} / \mathrm{ha})$ of grain $(10.7 \mathrm{~kg} / \mathrm{ha})$, Stover $(80.0 \mathrm{~kg} / \mathrm{ha})$ and total K uptake $(90.7 \mathrm{~kg} / \mathrm{ha})$ were significantly higher than the variety of Sona. The higher uptake increased due to better root development which results in better absorption of nutrient which lead to the yield. The uptake response also shows plant metabolic activity earlier reported similar response in nutrient uptake Hou et al.(2013), Khanal et al. (2017) and Singh et al. (2017).

\section{Economics}

The gross return, net return, and $\mathrm{B}: \mathrm{C}$ ratio invested have been worked out and presented in the Table 4. The different levels of nutrient management treatments and varieties significantly influenced the gross return, net return and $\mathrm{B}: \mathrm{C}$ ratio. All the levels of fertilizer application were found to increase the gross return, net return, and return per rupee which was significantly higher over control (no fertilizer application). Nutrient Expert based application of fertilizer recorded the highest gross return of Rs. 66021, highest net return of Rs. 37976 and highest $\mathrm{B}: \mathrm{C}$ ratio 1.35 which were significantly higher than all other treatments. The lowest gross return (Rs 29912), net return (Rs. 18500) and B:C ratio (0.80) were observed where no fertilizer application and the highest value was observed with Nutrient Expert and significantly highest among all the 
treatment. Similar result was observed by Wang et al. (2014). Among the two varieties, the Rajkumar variety gave significantly higher gross return, net return , $\mathrm{B}: \mathrm{C}$ ratio as compared to sona. Due to the productivity of maize was increased under NE and LCC based nutrient management practice which enhence optimum quantity of nutrient applied and also enhance the yield and profit of the crop (Vikram et al. 2015). Similar effects was observed for the varieties effect on the economics as reported by Bunker et al. (2011).

Table 4: Economics of Maize as affected by different levels of chemical fertilizers and varieties on Maize Hybrids

\begin{tabular}{|c|c|c|c|}
\hline \multirow[b]{2}{*}{ Treatments } & \multicolumn{3}{|c|}{ Economics } \\
\hline & $\begin{array}{l}\text { Gross } \\
\text { Return (₹) }\end{array}$ & $\begin{array}{l}\text { Net Return } \\
\text { (₹) }\end{array}$ & $\mathrm{B}: \mathrm{C}$ ratio \\
\hline \multicolumn{4}{|c|}{ Fertilizer } \\
\hline $\begin{array}{l}\mathrm{F}_{1}: \text { State } \\
\text { Recommendation }\end{array}$ & 64009 & 32803 & 1.05 \\
\hline $\mathrm{F}_{2}:$ Nutrient Expert ${ }^{\circledR}$ & 66021 & 37976 & 1.35 \\
\hline $\mathrm{F}_{3}:$ Farmer's practice & 50562 & 23069 & 0.84 \\
\hline $\begin{array}{l}\mathrm{F}_{4}: \text { LCC based } \\
\text { application }\end{array}$ & 65117 & 33663 & 1.07 \\
\hline $\mathrm{F}_{5}:$ Control & 29912 & 18500 & 0.80 \\
\hline SEm \pm & 1879 & 1879 & 0.07 \\
\hline $\mathrm{CD}(\mathrm{P}=0.05)$ & 5582 & 5582 & 0.21 \\
\hline \multicolumn{4}{|c|}{ Variety } \\
\hline $\mathrm{V}_{1}$ : Sona & 28229 & 49324 & 49324 \\
\hline $\mathrm{V}_{2}$ : Rajkumar & 28239 & 60925 & 60925 \\
\hline $\mathrm{SEm} \pm$ & 1879 & 840 & 840 \\
\hline $\mathrm{CD}(\mathrm{P}=0.05)$ & 5582 & 2496 & 2496 \\
\hline
\end{tabular}

\section{CONCLUSION}

It may be conclude that nutrient management has played an important role in achieving sustainability. The resulted in high price index of chemical fertilizers with their limited production, fertilizer cost, soil health, sustainability and pollution have gave rise to interest in precision nutrient management tools. The values for growth parameter yield, nutrient uptake and economics were significantly affected by different level of nutrient management and varieties. The application of nutrient on the basis of recommendation obtained from the decision support system like "Nutrient expert" and LCC based application proved superior over all other the treatments. Thus, cultivation of Rajkumar variety along with application of fertilizers on the basis of Nutrient expert based recommendation proved better for the cultivation of hybrid maize under lateritic soil of West Bengal.

\section{REFERENCES}

Bunker, M.C., Patel, A.M., Man, M.K. and Shaukat Ali. 2013. Influence of integrated nutrient management on productivity and quality of single cross hybrid maize (Zea mays L.) cv. HQPM 1.Advance Research Journal of Crop Improvement, 4(1): 54-58.

Hou Yun Peng Kong LiLi Yin Cai Xia Qin YuBo Li Qian Xie Jia Gu. 2013. Effects of fertilizer recommendation based on nutrient expert system on maize yield, nutrient uptake and utilization in Jilin province. [Chinese] Journal of Jilin Agricultural University; 35(5): 563-567.

Khanal, S., Dhakal, B., Bhusal, K. and Lal Prasad Amgain. 2017. Assessment of Yield and Yield Attributing Characters of Hybrid Maize using Nutrient Expert@ Maize Model in Eastern Terai of Nepal. International Journal of Environment, Agriculture and Biotechnology, 2(5): 2706-2709.

Kumar, D. and Jhariya, A.N. 2013. Nutritional, Medicinal and Economical importance of Corn: A Mini Review. Research Journal of Pharmaceutical Sciences, 2: 7-8.

Meena, R.R., Purohit, H.S., Khatik, M.L. Sumeriya, H.K. 2014. Productivity of maize (Zea mays L.) as influenced by site specific nutrient management. Annals of Agri Bio Research, 19(1): 38-44.

Nottidge, D.O., Balogun, R.B. and Ahaiwe, M.O. 2011. Integrated nutrient management, soil fertility and productivity of maize (Zea mays L.) in a derived savannaultisol of southeastern Nigeria. International Journal of Agriculture and Rural Development, 14(2): 644-648.

Pampolino, M.F., Witt, C., Pasuquin, J. M., Johnston, A. and Fisher, M.J. 2012. Development approach and evaluation of the nutrient expert software for nutrient management in cereal crops. Computers and Electronics in Agriculture, 88: 103-110.

Paramasivan, Kumaresan, M., Malarvizhi, K. R. Mahimairaja, P. and Velayudham, S.K. 2011. Nutrient optimization for sustainable productivity of hybrid maize (Zea mays L.) in Inseptisol. Advances in Plant Sciences, 24(1): 201-203.

Satyanarayana, T., Majumdar, K., Pampolino, M., Johnston, A.M., Jat, M.L., Kuchanur, P., Sreelatha, D., Sekhar, J.C., Kumar, Y., Maheswaran, R., Karthikeyan, R., Velayutahm, A., Dheebakaran Ga., Vallalkannan, S., Sherene, T., Ranjith, T.H., Shivamurthy, D., Aladakatti, Y.R., Chiplonkar, D., Gupta, R., Biradar, D.P., Jeyaraman, S. and Patil, S.G. 2013. Nutrient Expert: a tool to optimise nutrient use and improve productivity of maize. Better Crops, 97(1): 21-24.

Singh, V., Pant, A.K., Bahtnagar, A. and Bhatt, M. 2017. Evaluation of Nutrient Expert Based Fertilizer Recommendation for Growth, Yield and Nutrient Uptake of Maize Hybrids and Soil Properties in Maize-Wheat 


\section{ans}

Cropping System in Mollisol. Int. J. Curr. Microbiol. App. Sci., 6(10): 3539-3550.

Tetarwal, J.P., Ram, B. and Meena, D.S. 2011. Effect of integrated nutrient management on productivity, profitability, nutrient uptake and soil fertility in rainfed maize (Zea mays). Indian Journal of Agronomy, 56(4): 373376.

Vikram, A.P., Biradar, D.P., Umesh, M.R., Basavanneppa, M.A. and Rao, K.N. 2015. Effect of nutrient management techniques on growth, yield and economics of hybrid maize (Zea mays L.) in vertisols. Karnataka J. Agric. Sci., 28(4): 477-481.
Wang Yi, Lun Su Rui Guang Liu Ju Han Yan Lai Lu Yan Li Bai You Lu Tan Jin Fang. 2014. Effects of nutrient expert recommend fertilization on yield and fertilizer efficiency of summer maize in fluvo-aquic soil. [Chinese]Acta Agronomica Sinica, 40(3): 563-569.

Xinpeng Xu, Ping He, Shaojun Qiu, Mirasol F. Pampolino, Shicheng Zhao, Adrian M. Johnston, Wei Zhou. 2014. Fertilizer recommendation for maize in China based on yield response and agronomic efficiency. Field Crops Research, 15(7): 27-34. 